DOI https://doi.org/10.30525/978-9934-26-073-5-2-50

\title{
ВПЛИВ НОВИХ МЕДІА НА ФОРМУВАННЯ ЦІННІСНОЇ ОРІЄНТАЦІЇ МОЛОДІ
}

\author{
Шелюх О. М. \\ кандидат філологічних наук, \\ доиент кафедри гуманітарних наук \\ Національної академії сухопутних військ \\ імені гетьмана Петра Сагайдачного \\ м. Львів, Україна
}

Роль нових медіа в сучасному світі стрімко зростає, одночасно зростає і їх відповідальність за формування суспільних цінностей, особливо ціннісних орієнтирів молоді. Зростає відповідальність і в батьків, і в держави. Адже для молоді характерна певна соціальна незрілість, несформованість ціннісних орієнтирів, нездатність повною мірою адекватно прогнозувати наслідки своїх дій.

Через новітні засоби комунікації підліток часто лише пасивно споживає продукти маскультури, створені дорослими, стає беззахисним об’єктом маніпуляцій, оскільки діти й молодь 3 особливою довірою та відкритістю сприймають медіа-продукцію. Проте іноді їм не вистачає вміння критично проаналізувати побачене або почуте.

Створення світу, сприятливого для підростаючого поколіня, неможливе без створення безпечного інформаційного простору і формування культури взаємодії в соціальних мережах, певних правил безпечного користування новими медіа.

Якщо мислити глобально - дбати про чистоту інформаційного довкілля не менш важливо, ніж дбати про екологію довкілля навколишнього середовища, оскільки нові медіа сьогодні стали частиною нашого довкілля.

Завдання держави, на нашу думку, - не контролювати медіа простір, а максимально створити умови й забезпечити підтримку держави зусиллям громадськості для формування стандартів користування в нових медіа умовах «великого селища», щоб право на свободу слова не порушувало права свободи іншої людини в умовах глобалізації.

Якщо раніше традиційно вважалося, що на формування способу життя підростаючого покоління найперше впливають сім'я, школа та оточення, в якому індивід спілкується, то в урбанізованому, техногенному суспільстві все більш відчутним стає вплив медіа на соціалізацію молоді. 
Кордони сімейного простору розмиваються, утрачається його самодостатність і певна камерність: і за сніданком, і за вечерею молодь стає співучасником тих подій, які транслюють по телебаченню. В урбанізованому світі молоді люди все більше часу проводять, спілкуючись у соціальних цифрових мережах. Крім того, спілкування в реальному житті дуже часто витісняється іграми на мобільному телефоні, комп'ютері, переглядом ТВ.

На думку експертів, залежність від світу й культури суспільства дорослих виявляється, зокрема, у створенні спільного для них інформаційно-медійного простору, представленого Інтернетом, електронними медіа, ЗМІ. 3 інтенсивним розвитком телебачення, новітніх засобів комунікації, індивід із ранніх років життя соціалізується та імітує дорослих набагато швидше, ніж передбачалося.

Проблема впливу медіа на підліткову психіку все частіше опиняється в центрі уваги громадськості. У Британії на початку 2000-их започатковано проект-дослідження з цієї проблеми. У 2001 р. група вчених із Стенфордського університету на чолі 3 доктором Томасом Робінзоном визначили чіткий зв'язок між часом, який молодші школяри витрачають на телевізор та відеоігри, та агресивністю їх поведінки на дитячому майданчику.

На думку фахівців, тривала демонстрація насильства через медіа може призвести до зростання агресії, дратівливості, тривожності; послаблення чинників, що стримують агресію; притуплення чутливості до агресії. I хоча оцінки психологів, педагогів, батьків і представників медіа-індустрії розходяться, але очевидним є те, що зменшення толерантності $є$ результатом, зокрема, і ескалації насилля в медіапросторі.

Цікавими й вражаючими є результати дослідження Державного інституту розвитку сім'ї та молоді (ДІРСМ), проведеного ще в червні 2007 p. [4] (Розуміємо, що зараз ситуація значно серйозніша). За даними дослідження кожен третій молодий респондент (у віці 14-35рр.) відповів, що постійно користується комп'ютером, ще третина - iноді, інші - ніколи.

За даними дослідження ДІРСМ, практично майже всі користувачі комп'ютера відповіли, що грають на комп'ютері (різниця $2 \%$, що в межах теоретичної похибки). Якщо розглянути, яким іграм віддається перевага, то найбільшою популярністю користуються ігри-стратегії $(30 \%)$, а також «стрілялки» та «броділки». Найменше грають в Інтернет-ігри RPG (що пояснюється, в першу чергу обмеженим доступом до он-лайну). Кожен п'ятий у віці 14-17 pp. відповів, що скоріше обере гру на комп’ютері, ніж активний відпочинок. [7] 
Згідно з дослідженнями компанії DCF Intelligence, світовий ринок тільки онлайнових ігор зріс 3 3,4 млн. від 2005 року до 13 млн. у 207 році [5, с. 5].

Таким чином, нові медіа активно розвиваються у світі вцілому й в Україні зокрема. Вони інтенсивно входять до кожної української домівки та перетворюються на серйозний фактор впливу на молодь.

Зауважимо, що вплив нових медіа головно відбувається не лише через використання специфічних образів, символічних малюнків, але й через систему мовних засобів, які мають великий вплив на реципієнта й моделюють його соціальну поведінку. Аналізуючи особливості цих засобів, науковці мають підстави порушувати проблему чистоти, культури мовлення нових медіа, ЗМІ. Тому, вважаємо за необхідне, зосередити свою уваго, хоча б фрагментарно, на одній з проблемних ланок чистоти мовного засобу впливу нових медіа й ЗМІ на свідомість молоді - «мову ворожнечі» (Мова ворожнечі (англ. «hate speech») в широкому розумінні - це будь-яке самовисловлення з елементами заперечення принцииу рівності всіх людей у правах. У такому випадку самовисловлення відбувається за рахунок порівняння та «ієрархічного зіставляе різноманітних груп людей» з оиінкою «особистих якостей конкретних осіб на підставі їх належності до тієї або іншої групи». Таким чином, «мова ворожнечі» - термін, який відноситься до цілого ряду негативних висловів, починаючи від підбурювання $i$ закінчуючи ненавистю, зловживанням, дискредитаиією, образливими словами та епітетами, $i$, можливо також, надзвичайними прикладами упередження [1, с.11]. Фактично всі расистські і ворожі людині вислови можуть бути віднесені до цього терміну в нових засобах комунікаціі) [1, с. 11].

Як влучно зазначив Томас Фрідман, «сьогодні відбувається з'єднання всіх світових темпів знання в одну глобальну мережу, яка - якщо не втрутиться політика і тероризм - має можливість стати першою ластівкою епохи небаченого процвітання та оновлення» [6, с. 17].

Враховуючи темпи розвитку сучасних медіа та можливості, що відкриваються для вільного висловлення думок, де користувач стає і творцем інформації, слід особливу увагу приділяти змісту тих повідомлень, що розміщуються на сучасних медійних ресурсах. Зростає відповідальність за використання «мови ворожнечі», оскільки світ стає більш взаємозалежним, а отже - i вразливим. Подібні тенденції вже відбуваються у сучасному українському медійному середовищі. На їх існуванні наголосили фахівці Центру близькосхідних відносин під час свого виступу на радіо «Свобода», зазначивши, що «некоректні висловлювання в пресі, етнічні та релігійні образи можуть не лише породжувати негативні емоції, але й призводити зрештою до проявів насильства» [8]. Зокрема, подібне відбувається сьогодні у кримських 188 
медіа, які, висвітлюючи конфлікт між «слов'янською більшістю та репатріантами - кримськими татарами», ще більше його нагнітають, тим самим провокують до ескалації насилля і протистояння.

Таким чином, враховуючи особливості інформаційних процесів, стрімкого розвитку он-лайн журналістики, актуальною постає тема екології спілкування в соціальних мережах та уникнення використання «мови ворожнечі». Адже саме тут застосовуються найбільш гострі висловлювання, які часто носять ксенофобський, расистський характер, а молодь, яка у підлітковому віці часто перебуває в активному пошуку нових ідей, ідеалів; шукає способи самореалізації та самоідентифікації, неправильно інтерпретує почуті гасла, висловлювання чи побачені символи (в деяких з ігор застосовуються символи сатанізму (DOOM та інші), як відомо, фашисти теж використовували ці символи для ідеологічного підгрунтя нацизму). Найшвидше подібна інформація засвоюється молоддю. Тому в багатьох країнах саме молодь стає активним учасником націоналістичних і фашистських організацій.

Отже, формування ціннісних орієнтирів молоді, iї культури спілкування, зокрема в соціальній мережі через посередництво нових медіа, 3МI, неможливе без об'єднання зусиль держави, представників медіа, громадськості, батьків та дітей, без підвищення відповідальності в усіх учасників інформаційного поля.

\section{Література:}

1. Джакобс Дж., Поттер К. Злочини ненависті: Карне право і політика ідентичності. Нью-Йорк: видавництво «Оксфордський університет». 1998. C.11.

2. «Екологія мови» в контексті проблеми розмаїття культур і 3МІ. СЕІР: Айва Плюс ЛТД». 2008. 52 с.

3. Лемке Дж. Текстова політика. Дискурс та соціальна динаміка, 1995. С. 1.

4. Молодь України. Червень. 2007. (червень-липень 2007 року).

5. Мун Ирван. Игры не грушка. Профиль. - №37 (256). 18 сентября. 2006. С. 5.

6. Фридман Т. Плоский мир. - М., 2007. - С.17.

7. Детальніше: http// www.dt.ua/ 3000/3050/62027/; Жданова I. Гра завжди і назавжди. Урядовий кур'єр. 19 жовтня. 2007. 2007. С. 10

8. Жданова I. Чи подолаємо ігроманію? Розвязати проблему допоможе державна програма. Урядовий кур'єр. 26 січня. 2008. С. 10. 